\title{
Associations between age at first calving, rearing average daily weight gain, herd milk yield and dairy herd production, reproduction, and profitability
}

\author{
L. Krpálková, ${ }^{*} †$ V. E. Cabrera, $\ddagger^{1}$ J. Kvapilík, ${ }^{\star}$ J. Burdych, ${ }^{*} \S$ and P. Crump\# \\ *Department of Cattle Breeding, Institute of Animal Science, Přátelství 815, 10400 Prague 10 - Uhříněves, Czech Republic \\ †Department of Animal Husbandry, Faculty of Agrobiology, Food and Natural Resources, Czech University of Life Sciences Prague, \\ Kamýcká 129, 165 21, Prague 6 - Suchdol, Czech Republic \\ ‡Department of Dairy Science, University of Wisconsin, 1675 Observatory Dr., Madison 53716 \\ §VVS Verměřovice s.r.o, Verměřovice 159, 56152 Verměřovice, Czech Republic \\ \#College of Agricultural and Life Sciences, University of Wisconsin, 1675 Observatory Dr., Madison 53716
}

\begin{abstract}
The objective of this study was to evaluate the associations of variable intensity in rearing dairy heifers on 33 commercial dairy herds, including 23,008 cows and 18,139 heifers, with age at first calving (AFC), average daily weight gain (ADG), and milk yield (MY) level on reproduction traits and profitability. Milk yield during the production period was analyzed relative to reproduction and economic parameters. Data were collected during a 1-yr period (2011). The farms were located in 12 regions in the Czech Republic. The results show that those herds with more intensive rearing periods had lower conception rates among heifers at first and overall services. The differences in those conception rates between the group with the greatest ADG $(\geq 0.800 \mathrm{~kg} / \mathrm{d})$ and the group with the least ADG $(\leq 0.699 \mathrm{~kg} / \mathrm{d})$ were approximately 10 percentage points in favor of the least ADG. All the evaluated reproduction traits differed between AFC groups. Conception at first and overall services (cows) was greatest in herds with AFC $\geq 800 \mathrm{~d}$. The shortest days open $(105 \mathrm{~d})$ and calving interval (396 d) were found in the middle AFC group (799 to $750 \mathrm{~d}$ ). The highest number of completed lactations (2.67) was observed in the group with latest $\operatorname{AFC}(\geq 800 \mathrm{~d})$. The earliest AFC group $(\leq 749 \mathrm{~d})$ was characterized by the highest depreciation costs per cow at 8,275 Czech crowns (US\$414), and the highest culling rate for cows of $41 \%$. The most profitable rearing approach was reflected in the middle AFC (799 to 750 d) and middle ADG (0.799 to $0.700 \mathrm{~kg}$ ) groups. The highest MY $(\geq 8,500 \mathrm{~kg})$ occurred with the earliest AFC of $780 \mathrm{~d}$. Higher MY led to lower conception rates in cows, but the highest MY group also had the shortest days open (106 d) and a calving interval of $386 \mathrm{~d}$. The same MY group had the highest cow depreciation costs,
\end{abstract}

Received September 17, 2013.

Accepted June 12, 2014.

${ }^{1}$ Corresponding author: vcabrera@wisc.edu net profit, and profitability without subsidies of $2.67 \%$. We conclude that achieving low AFC will not always be the most profitable approach, which will depend upon farm-specific herd management. The MY is a very important factor for dairy farm profitability. The group of farms having the highest MY achieved the highest net profit despite having greater fertility problems.

Key words: age at first calving, heifer rearing, herd performance, profit

\section{INTRODUCTION}

Dairy farmers face a complex dilemma in minimizing costs associated with rearing heifers while ensuring or enhancing lifetime economic productivity. Decisions about heifer management interact with underlying biological aspects of growth, thereby influencing future profitability of the herd (Mourits et al., 1999). A basic approach to reduce costs is to shorten the nonproductive period of dairy heifers, which can be accomplished by breeding heifers earlier to reduce the age at first calving (AFC; Abeni et al., 2000; Daniels, 2010). Many studies suggest that the optimal AFC is $\leq 24$ mo (Mourits et al., 1999; Gabler and Heinrichs, 2003; Shamay et al., 2005; Stevenson et al., 2008). However, most of those researchers based their conclusions on milk production rather than whole economic measurements. Ettema and Santos (2004) found that only 2.7\% of US Holstein dairy farms achieved the recommended targets of AFC $\leq 24$ with liveweights $\geq 560 \mathrm{~kg}$. Hoffman et al. (1996) concluded that the possible advantages of reduced AFC, such as decreased feed costs, greater cumulative production per month of age, shorter generation interval, and lower overhead costs, must be weighed against such possible disadvantages as lower conception rates, increased dystocia, reduced milk production per lactation, diminished longevity, and the costs of increased nutrient density in the ration. Lower feed efficiency would be expected after calving from first lactation cows that are still growing at a fast pace when coming into milk. 
Although replacement heifers represent a large proportion (15 to $20 \%$ ) of the total cost of milk production, heifer rearing remains one of the least understood processes (Pirlo et al., 2000). The total costs of raising dairy replacements depend on the costs directly associated with growing heifers and the number of heifers grown. The highest cost category in the rearing period is feeding (Tozer and Heinrichs, 2001). In a dairy farm production system, management decisions concerning the rearing of young stock and replacement of dairy cows strongly influence one another (de Vries and Risco, 2005). Heikkilä et al. (2008) found that variation in results from other studies regarding $\mathrm{AFC}$, optimal replacement in the dairy herd, and consequently, the level of rearing costs depends upon local conditions and management on each farm. Market prices also vary, because they follow changes occurring in agricultural product markets. In most cases, however, an increase or decrease of costs and output prices by as much as $20 \%$ did not alter the optimal decisions (Heikkilä et al., 2008). Lee and Kim (2007) stated that high-producing (Holstein-Friesian) herds lose the benefit of their high production levels because of their increased morbidity and high probability for involuntary culling. Heikkilä et al. (2008) argued that the decline in fertility, which constitutes the most common reason for culling in highproducing herds, is associated with long-term selection for milk production. Mourits et al. (1999) found that genetic potential affects the growth of heifers. Highproducing herds need appropriate management during the rearing period to ensure that adult cows will be healthy and strong. Lee and Kim (2007) concluded that even when cows have high levels of production, they may not provide expected economic benefits due to their overall decline in other traits such as fertility, longevity, and health of cows. All these facts should be taken into consideration when planning the overall management of dairy cattle. The objective of this study was to evaluate the associations of AFC, ADG, milk yield (MY), and production and reproduction traits and economics in commercial dairy herds.

\section{MATERIALS AND METHODS}

\section{Data}

Data used in this study were recorded from 33 commercial dairy farms (17 with the Holstein breed, 8 with the Czech Fleckvieh breed, and 8 keeping both breeds in their herds). Our original data set consisted of 152 farms, and from those, we selected only 33 farms - those that did not perform any significant changes in feeding management, breeding operations, breeding populations (i.e., changes in breeding goal), or technologies used (milking parlor and housing upgrades) during the last 5 yr. All other farms were disqualified from further analysis and removed from our data set. The total numbers of cows and heifers were 23,008 and 18,139, respectively. All farms were closed dairy herds and the average herd size was 577 cows (SD: \pm 350 cows). The farms were located in the 12 regions within the Czech Republic. The animals in selected farms were kept in freestall barns. All the calves were housed in individual hutches equipped with buckets for water and a starter mixture. The diet of the heifers and cows consisted of a TMR (a mixture of forage and grain). The diet composition differed depending on the region, breed, management of each commercial farm, and feeding company services used. Data collected for each analyzed farm included averages for production and reproduction parameters, rearing costs, and economic parameters. The independent variables were AFC, ADG, and MY (Tables 1 and 2). In terms of biological and economic parameters, we were particularly interested in an earliest AFC of approximately $24 \mathrm{mo}$ and in high ADG above $0.8 \mathrm{~kg}$. Most studies considered this borderline as significant for optimal performance (Abeni et al., 2000; Shamay et al., 2005; Stevenson et al., 2008). The most important group for evaluation of MY was the group with highest-production herds. In the Czech Holstein breed (http://www.holstein.cz), a milk production of approximately $8,500 \mathrm{~kg}$ is the average breeding goal for MY, including first-parity cows and other cows. The farms' records of BW and respective reproduction and production traits were measured within the milk recording system (ICAR, 2012). Records of BW used for ADG were collected at 6,12 , and 14 mo of age in those 33 selected farms. The other dependent parameters are listed in Tables 1 and 2 .

The average of ADG, milk and milk replacer costs, total feed costs, and total costs per heifer (Tables 1 and 2) were taken from the new generation and other variables were based on the dams. Averages of AFC and MY were taken from the dams' population. Not all heifers calved at the time of the data collection, but the AFC of calved heifers did not differ more than \pm 1 standard deviation from average $\mathrm{AFC}$ of cows on analyzed farms. However, differences $<1$ standard deviation in AFC could still have an effect on our results. The same rearing conditions were observed for last $5 \mathrm{yr}$ in 33 selected farms. Data from the 33 farms used in this study were collected and verified by the Czech Statistical Office [CZSO (http://www.czso.cz/) and the Czech Moravian Breeders' Corp. (CMSCH; http://www.cmsch.cz/)]. The CZSO and CMSCH guaranteed that no significant management changes $( \pm 1 \mathrm{SD})$ occurred in these farms within the $5 \mathrm{yr}$ of data collection. 


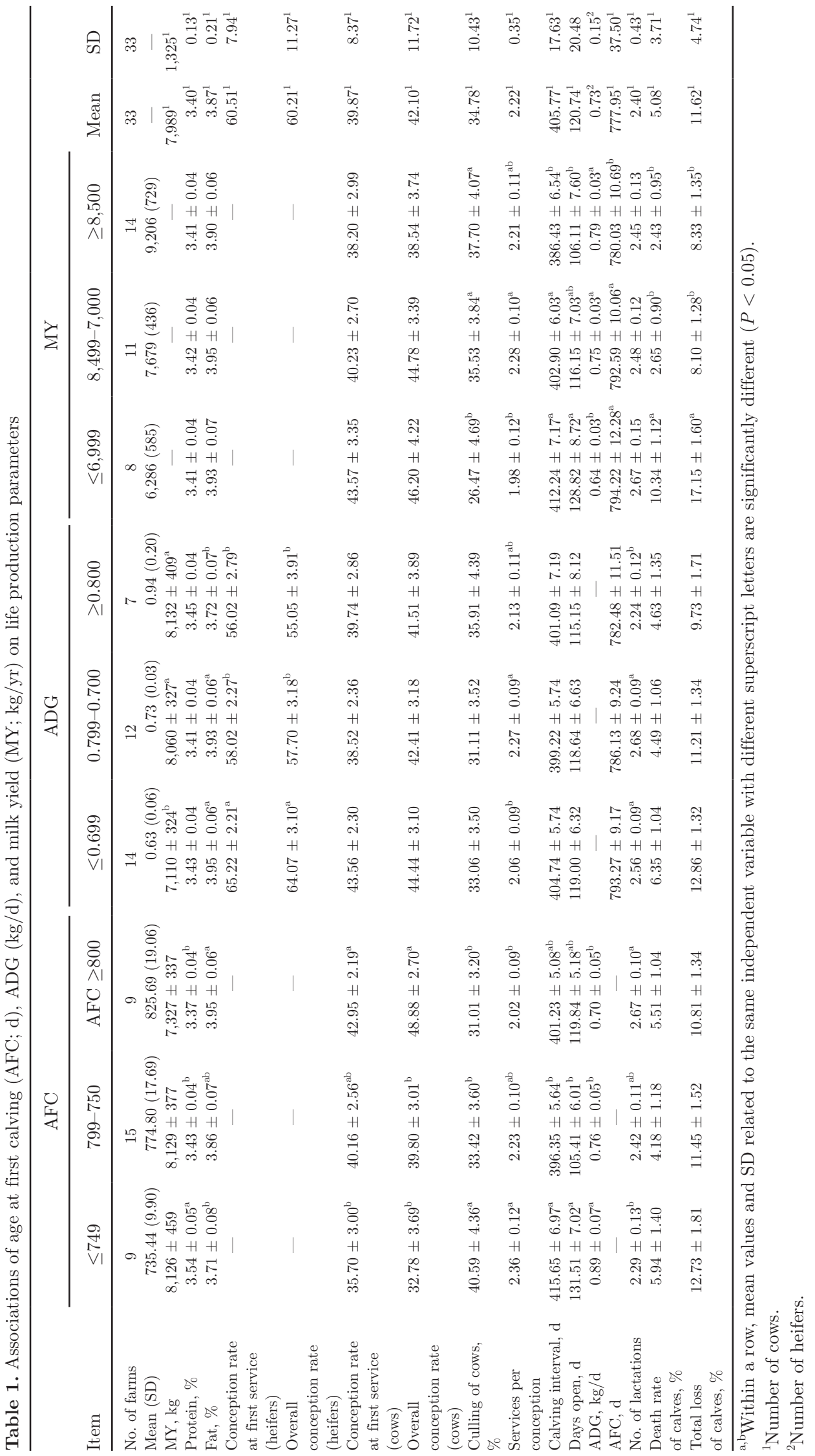


KRPÁLKOVÁ ET AL.

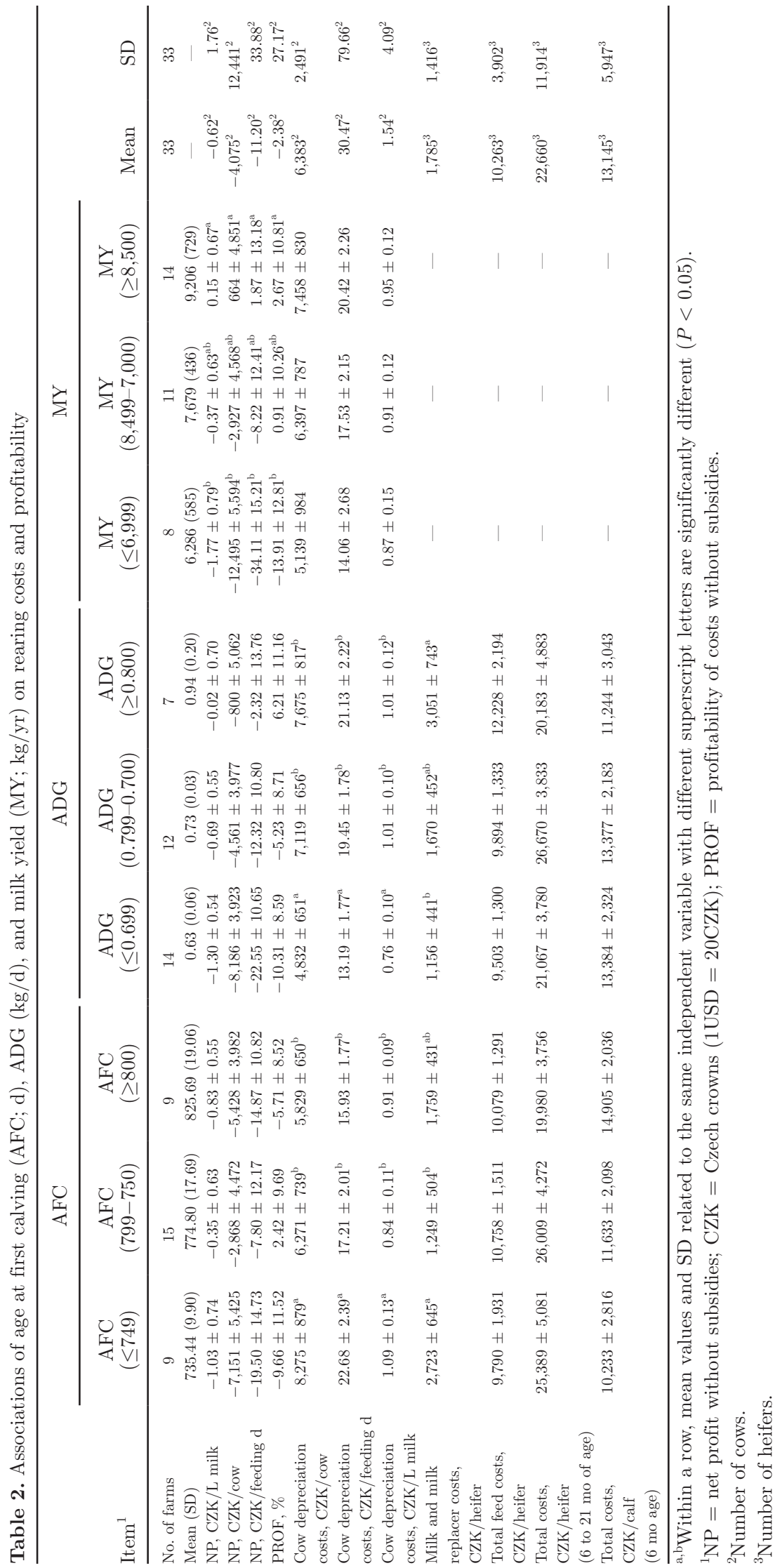


It was assumed that the heifers and their dams were reared at the same intensity and that the heifers' ADG values would represent those of their mothers. We used our evaluated groups as observed and did not attempt to study different strategies in these farms with respect to averages of heifers' ADG and dams' AFC. Therefore, the number of farms between the ADG and AFC groups needed not to be similar. No significant changes occurred in management, technologies used, or breeding protocols (i.e., changes in breeding goal), feeding, or breeding company services during the timeline the study lasted. Despite the higher breeding values of the replacement animals, only insignificant changes in the remaining management and conditions on the farms were expected in relation to the primiparous animals and, therefore, the new generation of animals could be considered to have the same management conditions as the older dairy cows they replaced. Costs and net profit for the dairy herds were calculated per liter of milk produced, per animal, and per feeding day according to certified methodology used in the Czech Republic (Poláčková et al., 2010). In that methodology, the number of feeding days corresponds to the age of the animal measured in days. Economic results are presented in Czech crowns (CZK), and 1 US dollar equals approximately 20 CZK.

The data were obtained using a questionnaire distributed to Czech dairy farmers. The different types of costs during the entire rearing period of heifers are listed in Table 2. Total feed costs over the entire rearing period for heifers included milk and milk replacer, cereal grains and concentrates, and roughages. Total costs for the entire rearing period for heifers included total feed costs, labor costs, costs of fuel and energy, costs for veterinary services and breeding operations, depreciation of intangible and tangible fixed assets, overhead costs, and other items. Total costs per calf at 6 mo of age were calculated from the same cost categories and items as those for heifers.

Milk production costs were calculated in a 2-step process. First, total accumulated costs for all cows were calculated, and second, indirect costs (i.e., costs of rearing calves and manure disposal) were calculated and subtracted from the total cost value (Poláčková et al., 2010).

Net profit (NP) without government subsidies (direct payments to support dairy farmers; CZK) was calculated as follows:

$$
\begin{gathered}
\text { TCc2 }=\text { TCc1 }- \text { CWIC; } \\
\mathrm{NP}=\mathrm{TSM}-\mathrm{TCc} 2
\end{gathered}
$$

where $\mathrm{TCc} 1$ = total accumulated costs for all cows, TCc2 $=$ total accumulated costs for all cows less indirect costs, CWIC = indirect costs (i.e., costs of rearing calves and manure disposal), and TSM $=$ total sales of milk.

The formula for calculating TCc1 includes the costs of purchased feed and bedding, self-produced feed and bedding, medicines and disinfectants, other direct costs and services, labor costs, depreciation of intangible and tangible fixed assets, depreciation of adult animals, costs of ancillary activities, and overhead (Poláčková et al., 2010).

Profitability of costs (PROF; in \%) was calculated according to Equation [3] and was designated as a measurement of business success (Poláčková et al., 2010).

$$
\mathrm{PROF}=\left(\frac{\mathrm{NP}}{\mathrm{TCc} 2}\right) \times 100 .
$$

The main advantage of this parameter was the possibility of yearly comparison among farms, regardless of herd size.

Culling of cows (cull; \%) was calculated according to Equation [4]:

$$
\text { Cull }=\left(\frac{N c c}{N c}\right) \times 100
$$

where $\mathrm{Nc}=$ overall number of cows in the evaluated period and Ncc = number of culled cows in the evaluated period.

\section{Statistical Analyses}

The data set was analyzed according to the following mixed model using PROC MIXED in SAS (SAS Institute, 2008). The Tukey test was used to determined significant differences among means (Verbeke and Molenberghs, 2000). The general statistical model was as follows:

$$
\mathrm{y}_{\mathrm{ijkl}}=\mu+\mathrm{B}_{\mathrm{i}}+\mathrm{R}_{\mathrm{j}}+\mathrm{D}_{\mathrm{k}}+\mathrm{e}_{\mathrm{ijkl}} \text {, }
$$

where $\mathrm{y}_{\mathrm{ijkl}}=$ value of the dependent variable (Tables 1 and 2$) ; \mu=$ overall mean; $B_{i}=$ ith breed effect $[i=$ 3: 17 farms with Holsteins (average number of cows $=$ 625), 8 farms with Czech Fleckvieh (average number of cows $=565)$, and 8 farms with both breeds in the herd (average number of cows $=982$ )]; $R_{j}=$ effect of the jth region of the farm $[\mathrm{j}=12=$ frequency of the studied farms (from 33 farms in total) in each of the 12 studied regions: South Bohemia: 1, South Moravia: 3, Hradec 
Králové: 2, Liberec: 1, Moravia-Silesia: 2, Olomouc: 3, Pardubice: 4, Pilsen: 4, Central Bohemia: 6, Ústí nad Labem: 2, Bohemian-Moravian Highlands: 4, and Zlín: 1]; $\mathrm{D}_{\mathrm{k}}=$ effect of the kth $\mathrm{AFC}, \mathrm{ADG}$, or MY class (Tables 1 and 2); and $\mathrm{e}_{\mathrm{ijkl}}=$ random error. Breed $\left(\mathrm{B}_{\mathrm{i}}\right)$ was considered as a fixed effect and region of farm $\left(R_{j}\right)$ as a random effect.

The regression coefficients and correlations were calculated using PROC REG and PROC CORR in SAS (SAS Institute, 2008) for better explanation and to ascertain the relationships between some selected variables: $\mathrm{ADG}$ and $\mathrm{AFC}, \mathrm{AFC}$ and days open, $\mathrm{AFC}$ and calving interval, MY and NP per cow, and MY and ADG.

\section{RESULTS}

\section{Growth Intensity and AFC}

The regression coefficients (intercept and slope) and correlation between ADG and AFC were 788.21 $(<0.001),-55.18 \mathrm{~d}(P<0.05)$, and $-0.34(P<$ $0.05)$, respectively. Average daily gain and AFC were analyzed separately (Tables 1 and 2), although only modest correlation was found between them. Average daily gain differed $(P<0.05)$ between the groups of the latest $\operatorname{AFC}(\geq 800 \mathrm{~d})$ and earliest $\operatorname{AFC}(\leq 749 \mathrm{~d})$ with means of 0.70 and $0.89 \mathrm{~kg}$, respectively. Dividing the ADG into groups evidenced that the greatest ADG was associated with the earliest AFC, but the difference between the high $(\geq 0.800 \mathrm{~kg})$ and low $(\leq 0.699 \mathrm{~kg})$ ADG group means was only between 10 and $11 \mathrm{~d}$ and was not significant (Table 1 ).

All of the evaluated reproduction traits differed significantly $(P<0.05)$ among AFC groups (Table 1$)$. The conception rate at first and overall services for cows was highest in herds of the group $\mathrm{AFC} \geq 800 \mathrm{~d}$. The latest AFC ( $\geq 800 \mathrm{~d})$ and earliest AFC ( $\leq 749 \mathrm{~d})$ groups had conception rates of 43 and $36 \%$ at first service and 49 and $33 \%$ overall conception rates, respectively. A similar result was seen in the number of services per conception, with only the groups AFC $\geq 800 \mathrm{~d}$ and AFC $\leq 749 \mathrm{~d}$ differing significantly from each other $(P$ $<0.05$; Table 1$)$. The shortest mean days open $(105 \mathrm{~d})$ and calving interval $(396 \mathrm{~d})$ were found in the middle AFC group (799 to $750 \mathrm{~d}$ ) and the longest days open $(132 \mathrm{~d})$ and calving interval $(416 \mathrm{~d})$ in the earliest AFC group ( $\leq 749 \mathrm{~d} ; P<0.05)$. The differences between the AFC groups were equivalent to approximately 1 estrous cycle for heifers (Table 1). The regression coefficients (intercept and slope) and correlations between AFC and days open were $285.96(<0.001),-0.21 \mathrm{~d}(P<$ $0.03)$, and $-0.39(P<0.03)$, and between AFC and calving interval were $535.15(<0.001),-0.16 \mathrm{~d}(P<$
$0.04)$, and $-0.36(P<0.04)$, respectively. Differences in MY between AFC groups were not significant and MY mean values were similar for the earliest $(8,126 \mathrm{~kg})$ and middle $(8,129 \mathrm{~kg})$ AFC groups. Mean lactations completed differed significantly $(P<0.05)$ among the AFC groups, with the highest mean being for the latest AFC group, at 2.67 lactations, and the lowest value being for the earliest AFC group, at 2.29 lactations. Similar results were seen for the ADG groups. The group of greatest ADG (which had the correspondingly earliest AFC) achieved 2.24 completed lactations. The analysis shows that those herds (having low AFC and high ADG) had lower conception rates among heifers at first and overall services. The differences between the group of greatest ADG $(\geq 0.800 \mathrm{~kg})$ and least ADG $(\leq 0.699 \mathrm{~kg})$ were around 10 percentage points for both aforementioned evaluated variables. The differences between culling of heifers and cows according to AFC are shown in Table 1 and Figure 1. The highest culling rate for cows (41\%) was found in the group with earliest AFC $(\leq 749 \mathrm{~d} ; P<0.05)$. The main reasons for culling of heifers were fertility problems (Figure 1) and the highest percentage was observed in the group with the latest AFC ( $\geq 800 \mathrm{~d})$. Reproductive problems tended to be the main reasons also for culling of cows, and other major reasons included movement disorders, mammary gland diseases, low production, and, in the group with latest $\operatorname{AFC~(~} \geq 800 \mathrm{~d})$, digestive diseases.

\section{Rearing Period and Economic Profit}

The economic associations of different evaluated groups in the rearing period of dairy heifers (ADG and AFC) are summarized in Table 2. Among all the dependent variables (Table 2), statistically significant differences $(P<0.05)$ were found only in milk and milk replacer costs and in cow depreciation costs. The highest milk and milk replacer costs were for the group with the earliest AFC ( $\leq 749$ d), at CZK 2,723 per heifer. Similar results were seen for the group with greatest ADG $(\geq 0.800 \mathrm{~kg})$, at CZK 3,051 per heifer, which led to lower AFC. No significant differences existed in the total feeding costs and total costs per heifer, and these costs showed great variability. The total costs per reared heifer averaged between CZK 20,000 and CZK 27,000 for all evaluated groups (Table 2). The greatest depreciation $(P<0.05)$ of cows was found in the group with earliest AFC ( $\leq 749 \mathrm{~d})$, at CZK 8,275 per cow, as it had the highest culling rate for cows of $41 \%$ (Table 1). High cow depreciation costs were also seen in the group of greatest ADG $(\geq 0.800 \mathrm{~kg})$, at CZK 7,675 per cow $(P<0.05)$. The middle groups for AFC (799 to 750 d) and ADG (0.799 to $0.700 \mathrm{~kg}$ ) were observed to reflect the most profitable approach to the heifer-rearing 
Heifers

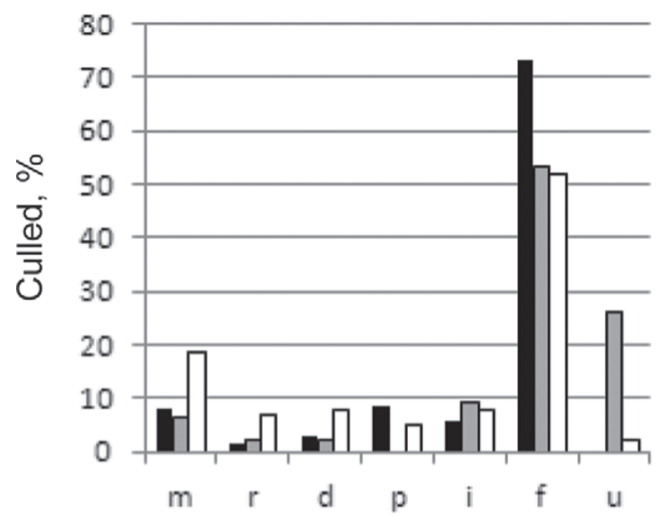

Cows

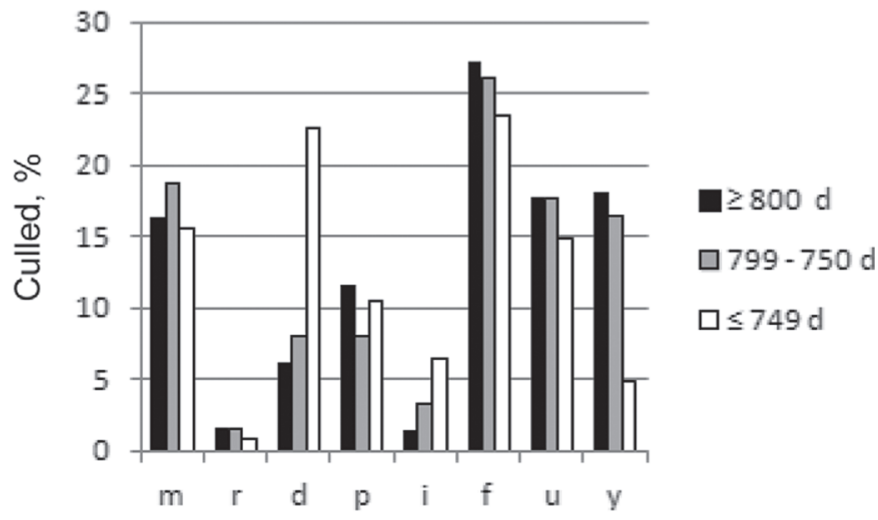

Cows

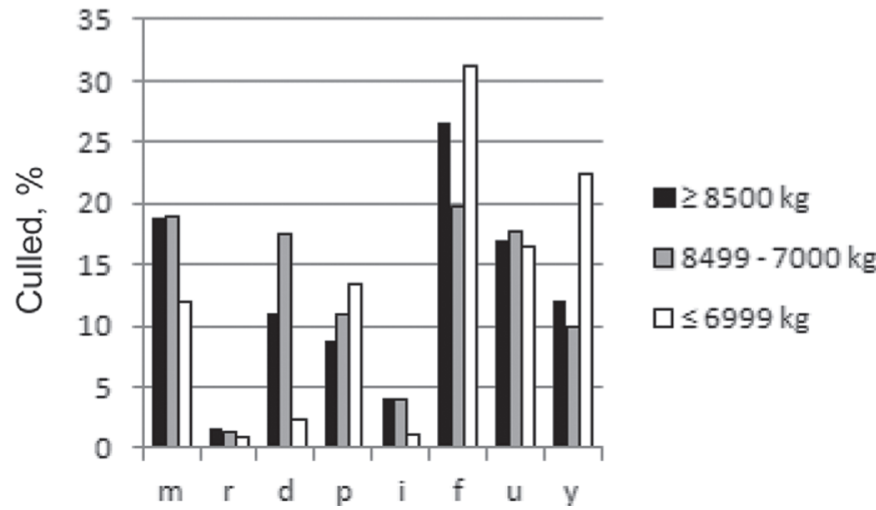

Figure 1. Reasons for culling of heifers (left panels) and cows (right panels) according to age at first calving (AFC; upper panels) and milk yield ( $\mathrm{MY}$; lower panels). $\mathrm{m}=$ movement disorders; $\mathrm{r}=$ respiratory diseases; $\mathrm{d}=$ digestive diseases; $\mathrm{p}=$ postpartum complications; $\mathrm{i}=$ injuries; $\mathrm{f}=$ low fertility; $\mathrm{u}=$ mammary gland diseases; $\mathrm{y}=$ low milk production. Age at first calving was grouped as high $(\geq 800 \mathrm{~d} ; \mathrm{n}=13$ farms; mean $=816.96 \pm 20.69 \mathrm{~d}$; median $=810 \mathrm{~d})$, middle $(799$ to $750 \mathrm{~d} ; \mathrm{n}=12$ farms; mean $=765.00 \pm 13.32 \mathrm{~d} ;$ median $=761 \mathrm{~d})$, and low $(\leq 749 \mathrm{~d} ; \mathrm{n}=$ 8 farms; mean $=733.97 \pm 9.47 \mathrm{~d}$; median $=735 \mathrm{~d})$. Milk yield was grouped as high $(\geq 8,500 \mathrm{~kg} ; \mathrm{n}=12$ farms; mean $=9,197 \pm 748 \mathrm{~kg} ;$ median $=8,838 \mathrm{~kg})$, middle $(8,499$ to $7,000 \mathrm{~kg} ; \mathrm{n}=11$ farms; mean = 7,679 $\pm 436 \mathrm{~kg}$; median = 7,555 kg), and low $(\leq 6,999 \mathrm{~kg} ; \mathrm{n}=8$ farms; mean $=$ $6,286 \pm 586 \mathrm{~kg} ;$ median $=6,335 \mathrm{~kg})$.

period, as measured by net profit of the herd without subsidies and profitability of costs without subsidies $(2.42 \%)$. This is despite the fact that these groups had the highest costs during the rearing period (Table 2).

\section{MY in the Herd}

The analysis of MY showed that herds with higher production achieved lower conception among cows at first and overall services, but the differences between groups were not statistically significant (Table 1). In the group with most MY $(\geq 8,500 \mathrm{~kg})$, the conception rates of cows at first and overall services were lowest at 38 and $39 \%$, respectively. Nevertheless, this highMY group also had the shortest days open (106 d) and calving interval (386 d; $P<0.05)$ compared with the middle $(8,499$ to $7,000 \mathrm{~kg})$ and lowest $(\leq 6,999 \mathrm{~kg})$ MY groups (Table 1), which had higher culling rates. The highest MY occurred for the earliest AFC group $(780 \mathrm{~d})$. The difference in AFC between the high- and low-MY groups was $14 \mathrm{~d}(P<0.05)$. The highest MY group had the greatest ADG and the earliest AFC $(P$ $<0.05)$. The herds with higher production $(\mathrm{MY} \geq 8,500$ $\mathrm{kg}$ and $\mathrm{MY}=8,499$ to $7,000 \mathrm{~kg}$ ) had lower losses of calves $(P<0.05)$. The differences between the highest and lowest MY groups for death rate and total loss of calves were approximately 8 to 9 percentage points. Differences according to MY in culling of cows are shown in Table 2 and Figure 1. The lowest culling of cows $(27 \%)$ was found in the lowest MY group. The difference in culling rates between the low and high MY groups was 10 percentage points and between the low 
and middle MY groups was 9 percentage points $(P<$ $0.05)$. Figure 1 shows that the main reason for culling of cows, regardless of MY group, was fertility problems. Other important reasons included movement disorders, mammary gland diseases, and, for the group with the lowest MY, low production.

The highest net profit per liter of milk of $0.15 \mathrm{CZK}$ and profitability of $2.67 \%$ without subsidies were achieved in the group with the highest MY, and this was statistically significant $(P<0.05)$ compared with the lowest MY group (Table 2). The highest reported cow depreciation costs were found in the highest MY group (Table 2), which was associated with the highest culling rate for cows $(38 \%)$. The regression coefficient [intercept (a) and slope (b)] and correlation (r) between MY and net profit were as follows: $\mathrm{a}=-26,959$ (0.04), $\mathrm{b}=2.86 \mathrm{~kg}(P<0.08)$, and $\mathrm{r}=0.31(P<0.08)$.

\section{DISCUSSION}

\section{Intensity of Rearing Dairy Heifers and Subsequent Performance}

Age at first calving is an important factor in the cost of rearing replacements in dairy herds and can be adjusted by altering growth rates (Curran et al., 2013; Froidmont et al., 2013). The average AFC in Holstein cattle has been recommended to be $\leq 24$ mo $(\leq 730 \mathrm{~d})$, while achieving body size that is adequate to maximize lactation performance, yet control rearing costs (Abeni et al., 2000; Tozer and Heinrichs, 2001; Shamay et al., 2005). The group with the earliest AFC $(\leq 749$ d) showed the lowest total cost per calf at 6 mo of age of CZK 10,233 (Table 2). Ettema and Santos (2004) reported that only few dairy farms achieved the recommended AFC target. In fact, the earliest AFC $(\leq 749$ d) was achieved by just 9 farms from the evaluated set (Tables 1 and 2). Even when heifers are fed similarly to achieve similar growth rates, variability in AFC is observed. This is dictated by reproduction efficiency at breeding. Poor reproduction increases variability in AFC, even though nutrition and growth rates may be adequate (Ettema and Santos, 2004). Reaching the goal of $\mathrm{AFC} \leq 24$ mo requires an ADG of between 0.7 and $0.8 \mathrm{~kg}$ in Holstein cattle (Abeni et al., 2000). The group with earliest AFC $(\leq 749 \mathrm{~d} ; \approx 24.5 \mathrm{mo})$ had a mean ADG of $0.89 \mathrm{~kg}$ (Table 1). Shamay et al. (2005) reported that an ADG of about $0.7 \mathrm{~kg}$ is optimal for achieving maximum performance. The highest MY $(8,129 \mathrm{~kg})$ was found in the middle ADG group (0.799 to $0.700 \mathrm{~kg} ; P<0.05$ ), and this group of herds also achieved the highest profitability of costs, at $2.42 \%$ (Table 2). Conversely, the lowest MY (7,327 kg) was achieved by the group having the least ADG $(\leq 0.699$ kg; Table 1). That least ADG group did, however, have the highest success in conception rate, at about $62 \%$. Hohenboken et al. (1995) contended that the relationship between ADG and milk production depends on genetic potential. In our study, the regression coefficient [intercept (a) and slope (b)] and correlation (r) between MY and total ADG were as follows: $\mathrm{a}=6,975$ $(<0.001), \mathrm{b}=1,382 \mathrm{~kg}(P<0.05)$, and $\mathrm{r}=0.16(P$ $<0.05$ ). Mourits et al. (2000) had remarked that the optimal AFC is far from uniform and stable. Wathes et al. (2008) found that optimal fertility and maintaining maximum performance was achieved in the AFC range of 24 to 25 mo. The highest MY group had the earliest AFC $(780 \mathrm{~d})$. The group with earliest AFC $(\leq 749$ $\mathrm{d} ; \approx 24.5 \mathrm{mo}$ ) showed the lowest fertility compared with the other evaluated groups $(P<0.05$; Table 1$)$. Conception rates at first and overall services were about $56 \%$ for heifers and about $34 \%$ for cows. The longest periods were also found in this group for days open (132 d) and calving interval (416 d). The AFC could be an important measure for monitoring and evaluating low fertility. The highest culling rate for cows of $41 \%(P<0.05)$ and, consequently, the highest cow depreciation costs of CZK 8,275 per cow $(P<0.05)$, and the lowest profitability $(-9.66 \%)$ were found for the same (earliest) group of AFC. Farmers assume that decreasing AFC will reduce costs of rearing heifers and increase their profits because these heifers will produce for longer (Van Amburgh et al., 1998; Mourits et al., 1999). However, the group with the earliest AFC $(\leq 749$ $\mathrm{d} ; \approx 24.5 \mathrm{mo}$ ) in the current study had, actually, the lowest number of completed lactations $(P<0.05)$ and the lowest profitability. Honarvar et al. (2010) stated that short herd life leads to high replacement costs and limits breeding selection. Hoffman et al. (1996) considered that lower AFC had to be evaluated in economic terms for each farm on the grounds that low AFC does not always lead to the most profitable solution. Looking at the highest net profit and profitability in our AFC and ADG groups, the most successful (nonsignificant differences) are the middle AFC group (799 to $750 \mathrm{~d}$ ) and the highest ADG group $(\leq 0.800 \mathrm{~kg})$. Curran et al. (2013) stated that to make a final economic evaluation of shorter rearing period, it is important to know the biological interrelationships between growth rate and subsequent reproduction and between growth rate and the ability for milk production. The most profitable groups of AFC and ADG achieved the highest milk production $(8,129$ and $8,132 \mathrm{~kg}$, respectively) and the shortest days open (105 and $115 \mathrm{~d}$, respectively). They had similar calving intervals, although the ADG group $(\leq 0.800 \mathrm{~kg})$ had the second shortest calving interval (401 d). The culling of cows in these most profitable groups of AFC (799 to $750 \mathrm{~d}$ ) and ADG ( $\leq 0.800 \mathrm{~kg})$ 
was between 33 and $36 \%$. The issue is complex. Heikkilä et al. (2008) found that the variability in results from several studies examining optimal AFC depended upon local conditions and the dairy herd management on each farm. Although the differences were not significant, the middle AFC group (799 to 750 d) achieved the highest profitability.

\section{High-Production Cows and Profitability}

A few years ago, numerous authors confirmed the decreasing fertility in high-producing dairy cows (Royal et al., 2000; González-Recio et al., 2004; de Vries and Risco, 2005). In the current study, the high-producing herds were shown to have the lowest conception rates (Table 1) among cows at first and overall services. However, the shortest days open (106 d) and shortest calving interval $(386 \mathrm{~d})$ were also observed for the same group. Kvapilík et al. (2012) found that a higher culling rate led to a lower calving interval, but without positive economic impacts. In this study, the culling rate of high-producing herds was the highest. The level of reproductive performance directly affects the economic performance of a dairy herd (Lee and Kim, 2007) and its production. Nonetheless, the group of high-producing herds was the most profitable in the current study. Mourits et al. (1999) concluded that price changes for milk and production inputs bore large income effects because management practices can only partially adjust to these changes. Kvapilík et al. (2012) reported that even as the average farm milk price in the Czech Republic during 2011 was CZK 8.26, the average of total cost of cows was CZK 8.55 per liter of milk and the average of cost of cows less the indirect costs (i.e., costs of rearing calves and manure disposal) was CZK 8.39 per liter of milk. It is evident that dairy farms in the Czech Republic would be operating at a loss without subsidies (Table 2). Heikkilä et al. (2008), too, concluded that price changes for milk and production inputs significantly affect farm profitability of costs. Therefore, an optimal replacement policy does not ensure a dairy herd's good economic performance. Nevertheless, Stevenson et al. (2008) agreed with the statement that the level of rearing heifers is one of the most important factors having a significant effect on subsequent reproduction performance and profitability in dairy herds. In the current study, the highest-producing and equally most profitable herds achieved the earliest $\mathrm{AFC}$, at $780 \mathrm{~d}(P<0.05)$, but also the highest culling rate of $38 \%(P<0.05)$. This resulted in this group having the highest cow depreciation costs. However, it was shown that neither AFC nor ADG determine the profitability (Table 2). Lucy (2001) shared the general opinion that increase in milk output is often connected to reduced reproductive ability. However, some studies do not confirm this view and consider that the problem lies in inadequate management and environmental conditions (especially the quality of feedstuffs) in highproducing herds (Kadokawa and Martin, 2006; Chiumia et al., 2013). The group of high-producing herds in the current study showed the lowest death rate for calves $(2.43 \%)$ and second-lowest total loss of calves (8.33\%). The reason for this probably lies in better nursing care for calves in high-producing herds. Fertility problems were the most common reasons for culling of cows and heifers. As noted by Kadokawa and Martin (2006), animals have certain biological limits and any disruption of homeostasis in their bodies leads to difficulties in their future performance. Our study showed that the highest-producing herds are the most profitable $(P<$ $0.05)$, although the highest levels of production also means highest culling rate $(P<0.05)$ and subsequent highest cow depreciation costs (nonsignificant differences). According to Lee and Kim (2007), high levels of production may not provide expected economic benefits in case of overall decline in other traits, such as longevity and health of cows.

\section{CONCLUSIONS}

A dairy herd is a complex system consisting of 2 interconnected parts: the milking herd and the replacement herd. Management decisions regarding replacement policy can have profound associations on the profitability of costs of the farm as a whole. Although it is often pursued as a management target, low AFC does not always lead to the most profitable outcome in dairy herd management. Local conditions on each farm remain important, and a heifer-rearing period that is more intensive ( $\mathrm{AFC} \approx 24.5 \mathrm{mo}$ ) can lead to a decline in fertility (calving interval, days open, and services per conception), an increase in depreciation of costs. Milk yield had a significant effect on net profits on the studied farms. The profitability without subsidies in the group with the highest MY was significantly the highest. The probability for successful return on investment improves when the herd management is based on quality heifer rearing. Nevertheless, an optimal replacement policy does not guarantee good dairy farm profitability, which is greatly influenced by the changing prices of inputs and outputs on agricultural markets.

\section{ACKNOWLEDGMENTS}

We are grateful to Gale A. Kirking for manuscript English editing. This research was supported by "S grant of MSMT CR" and by projects 0002701404 from the Ministry of Agriculture (Prague, Czech Republic) 
and QI91A238 from the National Agency for Agricultural Research (Brno, Czech Republic).

\section{REFERENCES}

Abeni, F., L. Calamari, L. Stefanini, and G. Pirlo. 2000. Effects of daily gain in pre- and postpubertal replacement dairy heifers on body condition score, body size, metabolic profile, and future milk production. J. Dairy Sci. 83:1468-1478.

Chiumia, D., M. G. G. Chagunda, A. I. Macrae, and D. J. Roberts 2013. Predisposing factors for involuntary culling in Holstein-Friesian dairy cows. J. Dairy Res. 80:45-50.

Curran, R. D., K. A. Weigel, P. C. Hoffman, J. A. Marshall, C. K. Kuzdas, and W. K. Coblentz. 2013. Relationships between age at first calving; herd management criteria; and lifetime milk, fat, and protein production in Holstein cattle. Prof. Anim. Sci. 29:1-9.

Daniels, K. M. 2010. Dairy heifer mammary development. Pages 69-76 in Proc. 19th Annu. Tri-State Dairy Nutrition Conf., Ft. Wayne, IN

de Vries, A., and C. A. Risco. 2005. Trends and seasonality of reproductive performance in Florida and Georgia dairy herds from 1976 to 2002. J. Dairy Sci. 88:3155-3165.

Ettema, J. F., and J. E. Santos. 2004. Impact of age at calving on lactation, reproduction, health, and income in first-parity Holsteins on commercial farms. J. Dairy Sci. 87:2730-2742.

Froidmont, E., P. Mayeres, P. Picron, A. Turlot, V. Planchon, and D. Stilmant. 2013. Associations between age at first calving, year and season of first calving and milk production in Holstein cows. Animal 7:665-672.

Gabler, M. T., and A. J. Heinrichs. 2003. Dietary protein to metabolizable energy ratios on feed efficiency and structural growth of prepubertal Holstein heifers. J. Dairy Sci. 86:268-274.

González-Recio, O., M. A. Pérez-Cabal, and R. Alenda. 2004. Economic value of female fertility and its relationship with profit in Spanish dairy cattle. J. Dairy Sci. 87:3053-3061.

Heikkilä, A.-M., J. I. Nousiainen, and L. Jauhiainen. 2008. Optimal replacement policy and economic value of dairy cows with diverse health status and production capacity. J. Dairy Sci. 91:2342-2352.

Hoffman, P. C., N. M. Brehm, S. G. Price, and A. Prill-Adams. 1996. Effect of accelerated postpubertal growth and early calving on lactation performance of primiparous Holstein heifers. J. Dairy Sci. 79:2024-2031

Hohenboken, W. D., J. Foldager, J. Jensen, P. Madsen, and B. B. Andersen. 1995. Breed and nutritional effects and interactions on energy intake, production and efficiency of nutrient utilization in young bulls, heifers and lactating cows. Acta Agric. Scand. A Anim. Sci. 45:92-98.

Honarvar, M., A. Nejati Javaremi, S. R. Miraei Ashtiani, and M. Dehghan Banadaki. 2010. Effect of length of productive life on genetic trend of milk production and profitability: A simulation study. Afr. J. Biotechnol. 9:3000-3010.

ICAR (International Committee for Animal Recording). 2012. International agreement of recording practices; Guidelines approved by the General Assembly held in Cork, Ireland on June 2012. Ac- cessed Feb. 27, 2014. http://www.icar.org/Documents/Rules and regulations/Guidelines/Guidelines_2012.pdf.

Kadokawa, H., and G. B. Martin. 2006. A new perspective on management of reproduction in dairy cows: The need for detailed metabolic information, an improved selection index and extended lactation. J. Reprod. Dev. 52:161-168.

Kvapilík, J., Z. Růžička, and P. Bucek. 2012. Main results and indicators for 2011. Pages 6-19 in Yearbook. Raising cattle in the Czech Republic. Českomoravská společnost chovatelů (ČMSCH) a.s., Prague, Czech Republic.

Lee, J.-I. and I.-H. Kim. 2007. Pregnancy loss in dairy cows: The contributing factors, the effects on reproductive performance and the economic impact. J. Vet. Sci. 8:283-288.

Lucy, M. C. 2001. Reproductive loss in high-producing dairy cattle: Where will it end? J. Dairy Sci. 84:1277-1293.

Mourits, M. C. M., D. T. Galligan, A. A. Dijkhuizen, and R. B. M. Huirne. 2000. Optimization of dairy heifer management decisions based on production conditions of Pennsylvania. J. Dairy Sci. 83:1989-1997.

Mourits, M. C. M., R. B. M. Huirne, A. A. Dijkhuizen, A. R. Kristensen, and D. T. Galligan. 1999. Economic optimization of dairy heifer management decisions. Agric. Syst. 61:17-31.

Pirlo, G., F. Miglior, and M. Speroni. 2000. Effect of age at first calving on production traits and on difference between milk yield returns and rearing costs in Italian Holsteins. J. Dairy Sci. 83:603-608.

Poláčková, J., J. Boudný, B. Janotová, and J. Novák. 2010. Methodology for calculation of costs and benefits in agriculture. Page 6 . Department of Agricultural Economics and Information, Prague, Czech Republic.

Royal, M. D., A. O. Darwash, A. P. F. Flint, R. Webb, J. A. Woolliams, and G. E. Lamming. 2000. Declining fertility in dairy cattle: Changes in traditional and endocrine parameters of fertility. Anim. Sci. 70:487-501.

SAS Institute. 2008. SAS/STAT ${ }^{\circledR} 9.2$ User's Guide. SAS Inst. Inc. Cary, NC.

Shamay, A., D. Werner, U. Moallem, H. Barash, and I. Bruckental. 2005. Effect of nursing management and skeletal size at weaning on puberty, skeletal growth rate, and milk production during first lactation of dairy heifers. J. Dairy Sci. 88:1460-1469.

Stevenson, J. L., J. A. Rodrigues, F. A. Braga, S. Bitente, J. C. Dalton, J. E. P. Santos, and R. C. Chebel. 2008. Effect of breeding protocols and reproductive tract score on reproductive performance of dairy heifers and economic outcome of breeding programs. J. Dairy Sci. 91:3424-3438.

Tozer, P. R., and A. J. Heinrichs. 2001. What affects the costs of raising replacement dairy heifers: A multiple-component analysis. J. Dairy Sci. 84:1836-1844.

Van Amburgh, M. E., D. M. Galton, D. E. Bauman, R. W. Everett, D. G. Fox, L. E. Chase, and H. N. Erb. 1998. Effects of three prepubertal body growth rates on performance of Holstein heifers during first lactation. J. Dairy Sci. 81:527-538.

Verbeke, G., and G. Molenberghs. 2000. Linear Mixed Models for Longitudinal Data. Springer-Verlag, New York, NY.

Wathes, D. C., J. S. Brickell, N. E. Bourne, A. Swali, and Z. Cheng. 2008. Factors influencing heifer survival and fertility on commercial dairy farms. Animal 2:1135-1143. 